\title{
Využití moderních analytických metod při řešení rizik a tvorbě územních strategií
}

ANDREA HRUŠKOVÁ, LUBOR HRUŠKA

Klíčová slova: protidrogová politika - strategické řízení - sociální rizika - politika založená na důkazech

\section{SOUHRN}

V současné době se do popředí dostávají sociálně-ekonomická a bezpečnostní rizika v území, které dlouhodobě ovlivňují stabilitu lokálních komunit. Pro identifikaci rizik je možno využít současné moderní technologie sběru dat měření výskytu nelegálních drog v odpadních vodách ve městech. Aplikace strategického řízení území založená na znalostech je podporována Evropskou unií, jedná se o tzv. prístup Evidence Based Policy. Tento přístup umožňuje managementu krajů a měst zacílit strategické plány do území a zároveň vyhodnotit i jejich efektivitu. Preferován je integrovaný př́stup k řešení rizik v území.

\section{ÚVOD}

V současné době dochází k proměně životního stylu obyvatel a do popředí se dostávají sociálně-ekonomická a bezpečnostní rizika v území. Pro identifikaci rizik je možno využít současné moderní technologie sběru dat a měření výskytu metabolitu návykových látek v odpadních vodách. Aplikace strategického rízení území založená na znalostech je podporována Evropskou unií, jedná se o tzv. přístup Evidence Based Policy' [1]. Projekt „Čistá voda - zdravé město: Cizorodé látky ve vodách podzemních, povrchových a odpadních jako důsledek lidské činnosti“” umožňuje managementu hlavního města Prahy a městských částí zacílit plány zdraví v souvislosti s agendou MA $21^{3}$, které podporují mimo jiné zdravý životní styl obyvatel. Výsledky lze také využít v rámci zacílení protidrogové prevence prípadně s měřením její efektivity. $V$ rámci projektu byla výzkumným ústavem ACCENDO - Centrum pro vědu a výzkum, z. ú., zpracována Socioekonomická studie prostorového rozložení obyvatelstva a identifikace rizikových oblastí z hlediska životního stylu obyvatel [2], kterou lze aplikovat podle potřeb veřejné správy.

Přínos článku spočívá v identifikaci možností využití výsledkư moderních výzkumných metod v oblasti, kde je nedostatek empirických dat, a jejich implementaci do strategického plánování veřejné správy, což umožňuje přesnější zacílení veřejných intervencí. Článek má multidisciplinární charakter a je zacílen především na představitele státní správy a územní samosprávy, dále pak na odbornou veřejnost.

\section{VYUŽITÍ EVIDENCE BASED POLICY VE VEŘEJNÉ SPRÁVĚ}

Tvorba strategií k posilování zdravého životního stylu, a tím i zdraví obyvatel by měla využívat princip „Evidence Based Policy“, tzn. prístup politik založených na důkazech. K tomuto principu se přistoupilo na konci 20. století, jelikož řada nestátních organizací se snažila ovlivnit decizní orgány tj. orgány s rozhodující pravomocí. $V$ tomto období došlo k veřejné a politické skepsi, kdy veřejnost zpochybňovala rozhodnutí veřejných orgánů, pokud nebyla podložena odbornými informacemi od relevantních expertů. Nutnost realizace politik na základě exaktních důkazů byla tak logickým vyústěním několika faktorů, mezi které patří zvyšující se vzdělanost a informovanost veřejnosti, jednoduchá dostupnost široké škály různých dat nebo dostupnost informačních technologií [3].

Cílem Evidence Based Policy je využít informace, které máme či můžeme získat, a přeměnit je na nezbytnou znalost pro zlepšení našich budoucích rozhodnutí. Př́stup upřednostňuje pečlivé analýzy a evaluace nad ideologií, marketingem či setrvačností aktuálního stavu. Samotný prístup Evidence Based Policy Ize rozdělit do čtyř na sebe navazujících principů [4]:

1. sestavení souborů informací o aktuálním stavu a o tom, co může v budoucnu fungovat včetně stanovení nákladů a prínosů,

2. monitorování efektivity provedených rozhodnutí prostřednictvím dopadových evaluací,

3. využití výsledků evaluací ke změnám v rozhodnutí směrem k nejefektivnějším variantám,

4. realizace inovací a testování nových přístupů.

Princip Evidence Based Policy je nezbytný pro zajištění nejlepšího možného využití veřejných zdrojů a dosažení nejvhodnějších dopadů zacílených strategií na život obyvatelstva. Politika založená na důkazech je efektivním prostředkem reakce na důležité aktuální i budoucí výzvy na všech úrovních veřejné správy a její správné využívání vede ke zvýšení efektivity rozhodnutí a řešení sociálních, ekonomických a environmentálních problémů.

\section{SOCIOEKONOMICKÁ STUDIE - PODKLAD PRO ROZHODOVÁNÍ V ÚZEMÍ}

Zpracovaná Socioekonomická studie prostorového rozložení obyvatelstva a identifikace rizikových oblastí z hlediska životního stylu obyvatel [2] je rozčleněna do tematických částí:

1. Uvedení do problematiky: Kapitola je zaměřena na stručný úvod do problematiky a dělena na podkapitoly Životní podmínky a jejich vliv na zdraví obyvatel, kde jsou rozepsána rizika, kterými může životní styl ovlivnit zdraví pražských obyvatel a možnosti ovlivňování životního stylu obyvatel městem (rozbor zákonů a strategických dokumentů Prahy ve vztahu k životnímu stylu obyvatel). 
2. Praha, její vývoj a porovnání s vybranými městy ČR nad 100000 obyvatel: Kapitola nastiňuje základní představu o Praze, obyvatelstvu na území Prahy, o obvyklých pohybech obyvatelstva, počtech trvalých a obvykle bydlících obyvatel a vývoji domácích a zahraničních turistů.

3 Vývoj Prahy v posledních 20 letech: Kapitola popisuje demografické údaje a další ukazatele v oblasti zdraví Prahy, opět v porovnání s vybranými městy ČR nad 100000 obyvatel (Praha, Brno, Ostrava, Plzeň).

4. Vnitřní proměny Prahy, městské části, místa setkávání: Kapitola je podrobněji zaměřena na pohyby obyvatel v Praze, proměny jednotlivých městských částí, jsou v ní vybrána místa, kde bývá pravidelně zvýšená koncentrace obyvatel jako jsou kulturní zařízení a turistické cíle, dále jsou zde zmapována pražská ubytovací zařízení.
Součástí výstupu výzkumného ústavu ACCENDO je kromě výše uvedené studie i interaktivní Integrovaná mapa rizikových oblastí, kde je možno zobrazovat zdravotní stav obyvatelstva (resp. standardizovaná míra úmrtnosti podle jednotlivých diagnóz), naměřený výskyt návykové látky podle povodí a další charakteristiky (výstup viz obr. 1)

\section{STRATEGICKÉ ŘÍZENÍ ÚZEMÍ}

Při prípravě a implementaci veřejných strategií v ČR se vychází z Metodiky prípravy veřejných strategií (aktualizace 2019), príijaté usnesením vlády ČR č. 71/2019. V rámci všech plánovacích dokumentů tj. strategií, koncepcí i plánů je kladen dưraz na analytickou část. $V$ některých plánech byla tato část donedávna podceňována, např. ve střednědobých plánech rozvoje sociální služeb nebo v krajských strategiích protidrogové politiky (naprr. Strategie protidrogové politiky Moravskoslezského kraje na období 2015-2020 má analýzu resp. popis situace na dvě strany).

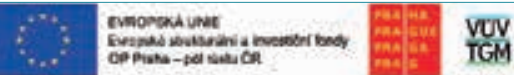 \\ Integrovaná mapa rizikových oblastí}

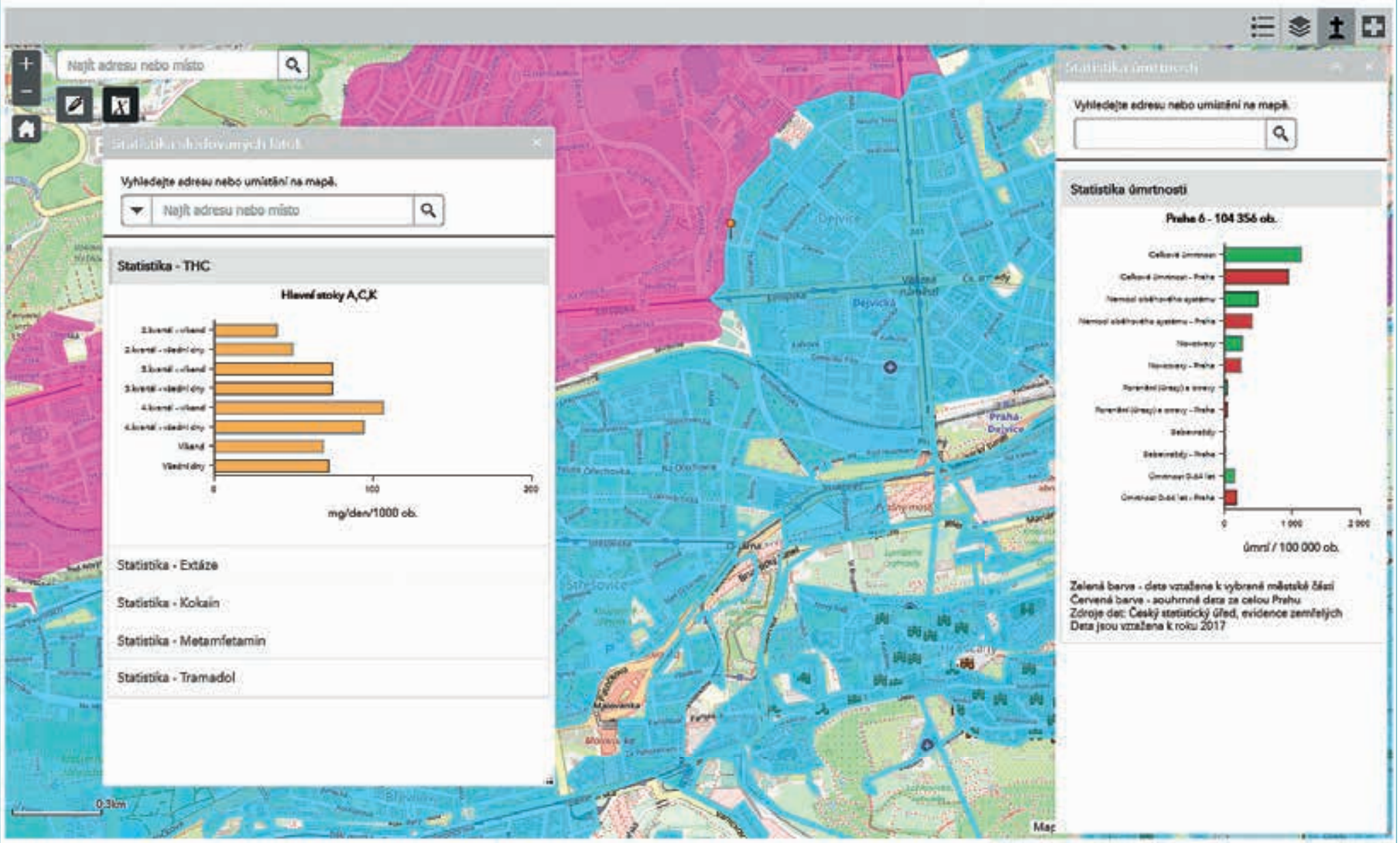

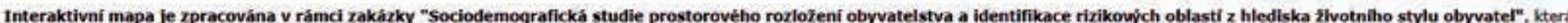

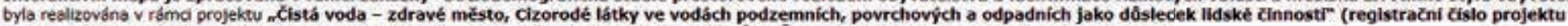
CZ.07.1.02/0.0/0.0/16_0.40/0000378) podpofeneho z Operatinho programu Prahs - pol rüstu C̈R.

Obr. 1. Integrovaná mapa rizikových oblastí (zdroj: ACCENDO, 2019)

Fig. 1. Integrated map of risk areas 
Tato nedostatečnost analytických částí u střednědobých plánů sociálních služeb byla upravena vyhláškou č. 387/2017 Sb., která s účinností od 1. ledna 2018 upravuje krom jiného strukturu a obsah analytických částí. Cílem analytické části je popsat situaci $\vee$ základních sociálních procesech $\vee$ území, zmapovat potřeby uživatelů, zmapovat situaci poskytovatelů z hlediska naplnění kapacit služeb a jejich ekonomické situace, potřeby obcí v území a jejich ochotu spolufinancovat sociální služby.

V oblasti protidrogových strategií na krajské úrovni žádné požadavky na analytickou část neexistují krom výše uvedené metodiky. Za kraje existují vybrané údaje uvedené ve Výroční zprávě o stavu ve věcech drog v České republice Národního monitorovacího střediska pro drogy a závislosti o drogové situaci.

$\checkmark$ prípadě popisu drogové scény v území existuje datová nedostatečnost. Pro zmapování této situace Ize využít kvantitativní i kvalitativní informační zdroje dat - Statistiky PČR o trestné činnosti související s užíváním a distribucí drog:

— postoj mládeže k uživání drog: dotazníkové šetření zkušeností a postojů s užíváním návykových látek,

- data o uživatelích: polostrukturované rozhovory s aktéry na protidrogové scéně (NNO terénní pracovníci, městská policie atd.),

— injekční užívání drog: statistika sběru použitých injekčních stříkaček,

- monitoring metabolitů drog v odpadních vodách.

Pro efektivní řešení této situace je nutný jednotný integrovaný prístup založený na rozvoji nových analytických metod a postupu v měření nelegálních drog v odpadních vodách. Klíčovou činností je měření a vyhodnocování socioekonomických procesů $v$ území pomocí kvantitativních a kvalitativních výzkumných metod včetně interpretace výsledků. Pro zmapování je vhodné propojit měření odpadních vod se sběrem informací z terénní práce sociálních pracovníků, adiktologů, zdravotníků a bezpečnostních složek (Policie ČR, Městská policie).

\section{Současné mezery v možné aplikaci integrovaného prístupu:}

- není jednoznačný globální cíl protidrogové politiky,

— z toho plyne nejasnost, jaká opatření mají subjekty $v$ protidrogové politice uplatňovat,

— jednotlivé subjekty naplňuji rozličné cíle, to vede k roztř̌řštěnosti, nepochopení a nízké efektivitě všech aktivit,

- celá situace prrispívá k růstu prostoru pro uživatele a distributory nelegálních návykových látek,

- subjekty protidrogové politiky nemají jasně vymezeny takové kompetence, které by je vedly $v$ jejich rưznorodé činnosti k uskutečňování společného globálního cíle,

— současná situace vede k vzájemnému konfliktu, názorovým střetům při naplňování specifických cílů.

Subjekty by měly při své činnosti respektovat globální cíl státní protidrogové politiky a tomu podřídit své specifické cíle. Globálním cílem pro všechny občany ČR je a vždy bylo snížení počtu uživatelů drog, zvýšení preventivní činnosti, tj. snižení nabídky a poptávky po drogách. Z výše uvedených důvodů obdobný globální cíl protidrogové politiky by měly mít i strategie $v$ jednotlivých krajích a městech. Pro naplnění tohoto cíle je nutné zavést monitoring spotřeby drog, který bude vycházet ze všech dostupných zdrojů dat o drogové scéně. Je nutné využít argumenty a možnosti v aplikovaném výzkumu, který zrcadlí potřeby veřejného zájmu bez osobního zaujetí. Základním pravidlem při stanovování cílů je postupovat věcně k naplnění veřejného zájmu a k ochraně veřejného zdraví obyvatel.

\section{DISKUSE A ZÁVĚR}

Specifický nástroj regionální politiky a komunitního plánování pro uplatnění územní dimenze představuji integrované přístupy, jejichž prínosem je zejména dosažení vyšší kvality strategického a komunitního plánování, řizení a efektivnější vynakládání finančních prostředků do jednotlivých oblastí. Jejich základním principem je věcná (vhodně a logicky provázané a potřebné tematické/ sektorové intervence), územní (intervence ve vhodném geograficky a ekonomicky spojeném území) a časová (realistický harmonogram a časové a věcné sladění intervencí) provázanost intervencí realizovaná na základě kvalitní strategie rozvoje území.

Integrovaný př́stup v prevenci kriminality představuje nástroj pro dosažení zejména vyšší kvality plánování v daném území, řízení a efektivnější vynakládání finančních prostředků. Integrovaný prístup obecně vyžaduje určitou časovou, územní a i kauzální provázanost jednotlivých typů intervencí. Integrované principy strategického řizení, které propojují koncepce bydlení, plány prevence kriminality, komunitní plánování a další strategie, jsou za předpokladu efektivního sběru a využití dat, jejich vyhodnocení, tvorby analýz a následného doporučení vhodným prístupem vedoucím ke snižení sociálních a bezpečnostních rizik. Nutným předpokladem pro zajištění fungujícího integrovaného př́stupu je zachování provázanosti kompetencí horizontálně např́č organizacemi na jednotlivých správních úrovních a zároveň na horizontální úrovni v jednotlivých správních celcích.

Užívání nedovolených návykových látek představuje jednu z hrozeb pro zdravé fungování společnosti. Řešení této otázky je proto zásadní. Kombinace moderních technologií a spolupráce různých subjektů územní správy umožňuje přístup k lokalizaci míst výskytu uživatelů těchto látek. Z konkrétní perspektivy by výsledky mohly přispět ke snižení uživání drog v těchto oblastech, na které budou zacíleny preventivní programy, ale z širšího pohledu by celá společnost mohla využít výhody z omezení celkové hrozby, ke kterému by došlo při cíleném odstranění rizikových faktorů.

\section{Poznámky}

1. Od začátku 21. století se Evropská komise princip Evidence Based Policy zavázala využívat při hodnocení a plánování svých legislativních návrhů za účelem maximalizace jejich pozitivních dopadů v ekonomické, sociální i environmentální oblasti. Výsledkem tohoto závazku je stav, kdy jsou v úrovni rozhodování Evropské unie zavedeny procesy, které zajištujij relevanci legislativních návrhů prostřednictvím hodnocení potenciálních dopadů [1].

2. Registrační číslo projektu: CZ.07.1.02/0.0/0.0/16_040/0000378), financováno z operačního programu Praha - pól růstu ČR.

3. Nástroj na zavádění udržitelného rozvoje na místní a regionální úrovni, přehled obcí/městských částí a regionů zapojených do agendy MA21 je dostupný na stránkách https://ma21.cenia.cz/cs-cz/přehledy/ma21vmapách.aspx. 


\section{Literatura}

[1] LEE, N. and KIRKPATRICK, C. Evidence-based policy-making. In: Europe: An Evaluation of European Commission Integrated Impact Assessments, Impact Assessment and Project Appraisal. 24:1, 23-33. Abingdon on Thames (United Kingdom): Taylor \& Francis, 2006, 11 p.

[2] HRUŠKA, L., FOLDYNOVÁ, I., HRUŠKOVÁ, A. a KUBÁŇ, D. Socioekonomická studie prostorového rozložení obyvatelstva a identifikace rizikových oblastí z hlediska životního stylu obyvatel - hlavn město Praha. 2018. Ostrava: ACCENDO - Centrum pro vědu a výzkum, z. ú.

[3] WILSON, J. Evidence-based policy making in the European Commission. Oslo (Norway): CICERO, 2015, 70 p.

[4] MILNER, J. and ELDRIDGE, M. From Evidence to Outcomes: Using Evidence to Inform Pay for Success Project Design. Washington, DC: Urban Institute, 2016, 11 p. Dostupné z: http://urbn.is/2bY8Ddh

\section{Autoři}

\section{PhDr. Andrea Hrušková}

凶andrea.hruskova@accendo.cz

doc. Ing. Lubor Hruška, Ph.D.

凶lubor.hruska@accendo.cz

ACCENDO - Centrum pro vědu a výzkum, z. ú.

Příspěvek prošel lektorským řízením.
USING MODERN ANALYTICAL METHODS FOR RISK MANAGEMENT AND THE CREATION OF TERRITORIAL STRATEGIES

\section{HRUSKOVA, A.; HRUSKA, L.}

ACCENDO - Center for Science and Research

Keywords: drug policy - strategic management social risks - Evidence Based Policy

Social-economic and safety risks in area are one of the main topics in these days, which in the long term affect the stability of local societies. For identification of these risks, we can use modern technology of data collection based on the analysis of illicit substances in city wastewater, as the cities are a high-risk areas from the social perspective in the Czech Republic. European Union supports application of knowledge-based strategic management. This so-called Evidence Based Policy Approach enables regional decision makers to develop strategic plans focused on current area problems and needs with possibility to evaluate the management effectivity. Integrated approach to deal with the social-economic risks is preferred in risk management. 